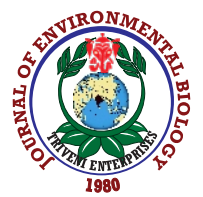

\title{
Evaluating the contributions of internship to landscape architecture education
}

\author{
A.A. Karadağ ${ }^{1}$, D. Demiroğlu', I. Sezen ${ }^{3 *}$ and T. Birişç ${ }^{4}$ \\ 'Department of Landscape Architecture, Faculty of Forestry, Düzce University, Düzce, 81620, Turkey \\ ${ }^{2}$ Department of Landscape Architecture, Faculty of Engineering and Architecture, Kilis 7 Aralık University, Kilis, 79000, Turkey \\ ${ }^{3}$ Department of Landscape Architecture, Faculty of Architecture and Design, Atatürk University, Erzurum, 25240, Turkey \\ ${ }^{4}$ Department of Landscape Architecture, Faculty of Agriculture, Ege University, Izmir, 35040, Turkey \\ *Corresponding Author Email : isiksezen@atauni.edu.tr
}

\begin{abstract}
Aim: The aim of this study was to determine the contribution of internship on landscape architecture education in Turkey.

Methodology: A questionnaire study on plantation and office internship was undertaken on 4th year students following the completion of their internship training. In all 411 questionnaire forms were filled in a semi structured interview/questionnaire. The descriptive statistics in the SPSS 22 program was used for the evaluation.

Results : The findings revealed that internship is considered necessary in terms of education and working life of a landscape architect. The findings have shown that internship duration was insufficient, its scope/number was inadequate, the placement of place was problematic, and its program was unclear, the process was uncontrolled and the evaluation was ineffective.

Interpretation: In order to increase the contribution of the internship to the landscape architecture education, proposals such as increasing the internship period, development of internship scope/number,establishment of internship place database, supervising internship process, creation of internship training program and effective internship exams have been proposed.

Keywords: Bachelor's degree, Internship, Landscape architecture, Turkey

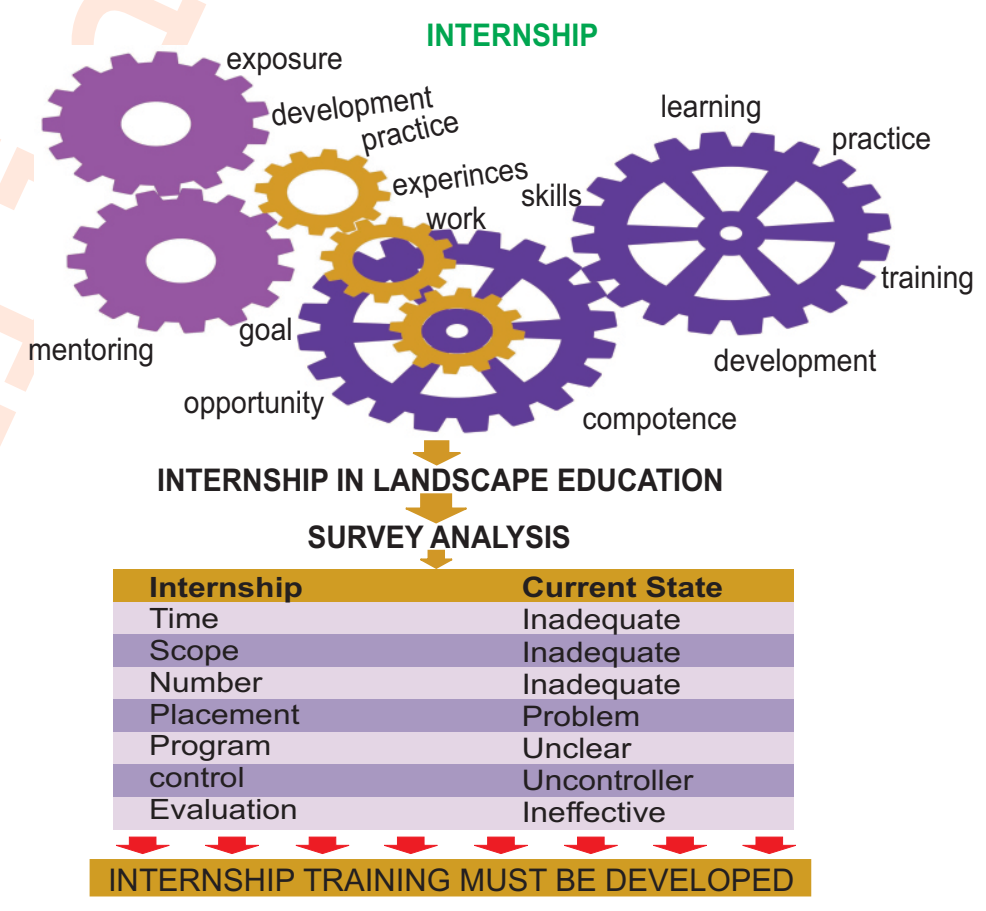

How to cite : Karadağ, A.A., D. Demiroğlu, I. Sezen and T. Birişçi: Evaluating the contributions of internship to landscape architecture education. J. Environ. Biol., 41, 365-374 (2020). 


\section{Introduction}

Landscape Architecture is an occupational discipline in which planning and design studies are carried out to create or organize landscapes in rural and urban areas in accordance with the sustainability principle (Nijhuis, 2013). It is also an applied science which aims to increase the functionality and quality of life in the physical environment, including planning, design, and management of land as well as principle of conservation and management of natural and cultural resources (Kalaycl et al., 2014).

Landscape architecture education was first introduced in 1909 at the Harvard University School of Architecture with the establishment of Landscape Architecture and Urban Planning Department (Yıldız et al., 2011, Atik et al., 2013). Today, about 293 universities in the world provide undergraduate and graduate level landscape architecture education. The landscape architecture education in these universities is oriented towards planning and/or design. In the training process, there are theoretical and practical lessons. In addition, some departments have internship training programmes. The internship is quite essential for landscape architecture education (Demiroğlu et al., 2014).

Currently, the scientific research in internship training in landscape architecture is insufficient and there is no statistically reliable and applicable "scale" for this. Internship studies are the basic elements of education programs and quality education (Çetin, 2005; Dağıstanlıoğlu et al., 2012, Demiroğlu et al., 2014; Erdoğan et al., 2014; Kalaycı et al., 2014; Olcay et al., 2015; Karaman et al., 2017). It is the most important way of giving students experience and skills. Students get chance to recognize the business environment, compare theoretical and practical knowledge, increase their professional experience (Karaman et al., 2017), consolidate the knowledge and skills they acquire in real life, learn new developments in the sector as well as related technologies and recognize different workplaces (Çetin, 2005; Karaman et al., 2017). In view of this, internship practice is generally available in undergraduate education (Anonymous, 2015). For theoretical information to access analysis and synthesis stage during landscape architecture education, compulsory internship training has become a part of the training. The most effective stage where theoretical knowledge can be transferred to practice in landscape architecture is internship education as in other applied professional fields (Kalayci et al., 2014).

In Landscape Architecture training, the compulsion and duration of internship vary from country to country; even change within universities in the same country. For instance, internship in landscape architecture training is obligatory in Belgium. Some universities have internship specialists, who provide service to students in placing them to internship sites with domestic and foreign offices and institutions. In other universities, students themselves must apply for internship. It is stated that France does not have compulsory internship but there are some landscape architecture offices, which occasionally advertise internship training varying between 1 to 8 months for the students both from country or abroad. There is a mandatory internship in all universities in Germany which have landscape architecture department. While many universities require internships during some teaching periods, there is a requirement in the universities of Applied Sciences that at least 3 months of internship is a prerequisite to graduation.

In Germany, there are two general methods of internship performed. The first method is conducted at the universities of Kassel, Nürtingen and Weihenstephan-Triesdorf and two internships each taking 20 weeks are carried out, one of which is in the office and management and the other is on landscape construction. Students who had participated in the practice of professional internship in the field of landscape construction were exempted from the first applied period. The second method was applied in TU Hannover, HTW Dresden, TU Berlin Universities. During the teaching period, only office and managerial internship applications were made. In the field of landscape construction, it is required to have applied experience before graduation. Intensive practical training is a characteristic of German Universities. The basic philosophy of this application is that the theoretical knowledge is reinforced by practice and turned into a professional experience. Most of the universities have internship professionals who manage the database of internship sites. Since internship practice is part of the university education and compulsory, trainees are usually paid low wages $(€ 300-600)$.

Internship practices in Italy are also changing due to recent university reform. Following the reform, architecture faculties have been redesigned to include many different fields such as architecture, planning, landscape architecture in undergraduate and graduate education ( $3+2$ years). Students are required to pass "Professional Practice Exam" in order to use their titles. According to this regulation, applicants for this exam must do their internship training at undergraduate and graduate levels under different terms and conditions. Students at undergraduate level must gain experience in landscape construction, public institutions and private offices for 6-8 weeks. Internships at Genova University are organized by agreements between universities and internship places. A group of teaching staff is responsible for the placement of students at internship places and for checking the work of students together with internship staff. At graduate level, the internship is supervised by "Ordinedegli Architetti, Pianificatori, Paesaggisti, Conservatori", the professional institution of Italian architects, landscape architects and planners, and minimum 9-10 months of internship period is required.

Internship is compulsory in Dutch Universities. Students are obliged to complete internship in $3^{\text {rd }}$ year of their university 
education, in two parts, with a total of 3 months (50 working days), each in different offices.

Landscape architecture students in the UK are required to work in office or institution for 4 years after being trained for 3 years. While some universities provide placements for students to work in, many universities expect their students to establish necessary connections for themselves.

Internship in the US landscape architecture departments is merely advisory. Only one college requires obligation to work in a firm for 1 year in-between $3-4^{\text {th }}$ years and it is supervised by the instructors. Yet, there is an internship practice in the landscaping contracting departments (Kalaycı et al., 2014).

Landscape architecture education in Turkey started with the establishment of "Ornamental Flora Branch" in 1933 under Higher Institute of Agriculture. Ankara University was founded in 1946 and the department in question continued its activities under the name of "Garden Architecture and Forestation Department" in the Faculty of Agriculture. In 1968, the Department of Landscape Architecture was established as one of the 10 departments within the Faculty of Agriculture in Ankara University (Kesim and Mansuroğlu, 2000; Uzun and Kesim, 2008; Atik et al., 2013). Today 55 universities have "Department of Landscape Architecture" (PEMCON 8th.Term Presidency, 2017). These departments provide education in tandem with agriculture, architecture, forestry, architectural-design, fine arts-designarchitecture and engineering-architecture faculties (URL-1). The training period is 4 years. Internship is an important part of this training and of should be completed in order to become a graduate. Erdoğan et al. (2014) had investigated the internship training regulations of 24 landscape architecture programs at undergraduate level. Internships were mostly done in 2 semester during summer holidays after 4th and 6th semesters. In addition, it was found that the period of internship varied from 40 to 72 working days in total, according to the internship guidelines investigated in the study.

This study was carried out to determine the contribution of plantation and office internship on landscape architecture education in Turkey. In addition, based on the findings of the study, to develop recommendations for the development of internship training.

\section{Materials and Methods}

The main material of the study consists of students who have completed internship education in landscape architecture departments. In the study, a questionnaire study was used to obtain data. In the preparation of the questionnaire questions, literature related the scope of the study was used. The questionnaire consisted of 4 sections and a total of 20 questions. The first part consists of 8 questions about demographic characteristics; the second part consists of 4 questions in which nursery internship is evaluated; the third part consists of 4 questions in which the internship is evaluated and the last part consists of 3 questions in which the contributions of the internship training are evaluated. In addition, a 5-point Likert scale was used to evaluate the variablesAccording to the Likert scale, (1) is not sufficient, (2) is inadequate, (3) is moderately adequate, (4) is sufficient (5) is highly adequate. Also attention has been paid that the questionnaire was short and easy to understand. First of all, the accuracy of the form in terms of grammar rules was presented to the opinion of 1 Turkish teacher. Then the form was presented to the view of 3 landscape architects. In this context, the statements were corrected again and the number of questions was reduced.

In a study using questionnaire, the priority was to decide the number of samples. The universe of this study was $630(\mathrm{~N})$ 4th-year undergraduate students in 2014-2015 academic year (in 21 departments). The number of $4^{\text {th }}$ year was obtained from the related departments.

The estimated deviation was estimated as $d=0.05$, the standard deviation was estimated as 0.5 and the confidence level was taken as $(1-\alpha)=0.95$ based on this scale. t-value corresponding to the confidence level was 1.96. The sample size was calculated by the following formula (Güngör, 2006).

$$
n=N t^{2} p . q / d^{2}(N 1)+t^{2} p . q
$$

The sample size was determined as 239 people. To increase the representation capability of the study, the sample size was increased and 411 questionnaire forms were filled. The data were determined by random selection from the universe on a voluntary basis.

Those who filled the form questionnaire were called participants. The questionnaire form was obtained by filling in a face-to-face interview. The participants were told that the questionnaire aimed to make generalizations and it was ensured that the participants would be able to answer the questions in a comfortable and friendly environment without being influenced by others.

SPSS 22 software program was used for statistical analyses. Therefore, the questionnaire forms were first numbered, each option in the questionnaire was assigned a value to transfer the questionnaire to the computer programme. The descriptive statistics in the SPSS 22 program was used for evaluation.

\section{Results and Discussion}

The study was conducted in undergraduate landscape architecture degree programs in Turkey (21 departments). The questionnaire was evaluated with a total of 411 participants. 
Demographic features : 411 students participated in the study. $70 \%$ participants were female and $29 \%$ male. $1 \%$ of respondents did not answer the questionnaire. $90 \%$ participants aged between 20-25 years; $28 \%$ between $25-30$ years; $2 \%$ between $30-34$. Almost $2 \%$ of the participants did not answer this question. $96 \%$ of the participants were from the state and $4 \%$ from private universities. Participants were studying in 14 different universities (Bartin, Ege, Mustafa Kemal, Çukurova, Ataturk, Istanbul, Karadeniz Technical, Suleyman Demirel, Namik Kemal, Çanakkale Onsekiz Mart, Akdeniz, İstanbul Teknik, Yeditepe, Düzce) and in 5 different faculties (Forestry, Architecture, Agriculture, Architecture and Design, Fine Arts, Design and Architecture).

The most important factors for participants to choose the landscape architecture department were love for nature, environment, and design (Table 1). At the end of the training, the participants indicated that they plan to work in plantations, construction sites,and public institutions-organizations (Table 2). When participants pre-training experiences were questioned, $77 \%$ stated that they did not have any experience while $2 \%$ had. In addition, $2 \%$ of the participants did not answer this question.

Plantation internship questionnaire results : $59 \%$ of the participants think that the plantation internship period is sufficient (Table 3). For this reason, $79 \%$ of the participants did not extend their internship period. In addition, $12 \%$ of the participants did not answer this question.

Participant's preference for choosing plantation internship place is its "being in the city where he lives, having experienced staff, landscape architects working in the workplace, and workplace showing care for an internship" (Table 4).

When participants were asked about the institution/ organization where they do their plantation internship, "intern supervisor/manager guidance, work related to the internship topic, interns benefiting from workplace facilities, meals provided" items were found to be adequate. This assessment shows participants basic expectations and that these expectations are met (Table 5). When participants were asked about their ideas on the contribution of plantation internship, it was found that "Gaining experience in human relations and group work, learning pruning methods, learning workers working system and organization (business management), plant care (fertilization, disinfestation, etc.) applications, herbaceous plant species used in plant design, plantation and greenhouse operations / management, plant production methods, the work area related to the profession and woody plant species used in plant design, development of oral and written communication skills in professional discipline, associating theoretical information with application, understanding professional and ethical responsibilities, recognizing plant diseases and pests - learning combat methods, learning the pricing criteria of plants" items were found to be adequate. This assessment can be expressed as the main contribution of plantation internship (Table 6).

Office internship questionnaire results : Participants think that the office training is adequate (60\%) (Table 7). For this reason, $68 \%$ of the participants did not extend their internship period. In addition, $19 \%$ of the participants did not answer this question.

When the participants were asked about their preference for plantation internship place, "experienced staff, landscape architect working in the workplace, workplace giving importance to internship, being in the city where one lives, being an ideal place to work after graduation, training interns" items were found to be adequate. This evaluation highlighted the basic expectations of the participants' office internship (Table 8).

When participants were asked about the institution/ organization where they do internship, "Internship Manager/

Table 1 : Participants' reasons for choosing the landscape architecture

\begin{tabular}{lll}
\hline Preference reasons & Number of respondents & Average \\
\hline Loving nature and environment & 397 & $3.8766( \pm 1.08124)$ \\
Loving design & 399 & $3.6892( \pm 1.27151)$ \\
Being an architecture-oriented department & 397 & $3.2897( \pm 1.32924)$ \\
Loving plants & 397 & $3.2191( \pm 1.26125)$ \\
Having one's own workplace & 400 & $3.1775( \pm 1.69208)$ \\
Nothaving enough score for another department & 397 & $3.1511( \pm 1.31899)$ \\
Loving construction work & 396 & $3.0682( \pm 1.35867)$ \\
Ease of finding a job in private sector & 397 & $2.8010( \pm 1.30971)$ \\
Family Influence & 396 & $1.9242( \pm 1.29627)$ \\
Better job opportunities in the state & 397 & $1.9169( \pm 1.15279)$ \\
The effect of environment & 389 & $1.7738( \pm 1.16222)$ \\
Having the department in one's city & 392 & $1.7219( \pm 1.28804)$ \\
The influence of one's friends & 396 & $1.5328( \pm 1.00199)$ \\
The family having a landscaping company & 396 & $1.3182( \pm 0.86553)$ \\
Other & 15 & $4.6000( \pm 0.73679)$ \\
\hline
\end{tabular}


Table 2: Place where the participants want to work after graduation

\begin{tabular}{lll}
\hline Workplace & Number of respondents & Average \\
\hline Plantation & 334 & $4.4790( \pm 1.58574)$ \\
Building site & 331 & $3.7855( \pm 1.70006)$ \\
Public institutions-organizations & 331 & $3.7069( \pm 2.57046)$ \\
Planning Bureau & 333 & $3.4865( \pm 1.55345)$ \\
Municipality & 336 & $3.2113( \pm 1.70688)$ \\
Design bureau & 333 & $2.6096( \pm 1.63844)$ \\
\hline
\end{tabular}

Table 3 : Participants' ideas on the period of plantation internship

\begin{tabular}{lll}
\hline Ideas on Duration of Internship & Frequency & Ratio (\%) \\
\hline Enough & 241 & 59 \\
Notenough & 73 & 18 \\
Too much & 34 & 8 \\
No idea & 14 & 3 \\
Total & 362 & 88 \\
Too little & 49 & 12 \\
Grand total & 411 & 100 \\
\hline
\end{tabular}

Table 4 : Criteria for participant's plantation internship preference

\begin{tabular}{lll}
\hline Criteria & Number of respondents & Average \\
\hline Being in the same city & 351 & $3.3020( \pm 1.82678)$ \\
Experienced staff & 349 & $3.1891( \pm 1.51004)$ \\
Landscape architect working in the workplace & 350 & $3.1314( \pm 1.57883)$ \\
Workplace giving importance to internship & 353 & $3.0765( \pm 1.54932)$ \\
Agood reference for graduates & 352 & $2.9858( \pm 1.51998)$ \\
Turkey being a good plantation site & 352 & $2.8693( \pm 1.48304)$ \\
Other interns working & 350 & $2.6943( \pm 1.48757)$ \\
Training the interns & 348 & $2.4138( \pm 1.41260)$ \\
Being an ideal place to work after graduation & 350 & $2.3257( \pm 1.45108)$ \\
Being in the city where one studies & 352 & $2.2727( \pm 1.72943)$ \\
Department recommendation & 352 & $2.0114( \pm 1.45977)$ \\
Previous Interns' Recommendation & 349 & $1.8510( \pm 1.26429)$ \\
Not finding another plantation & 352 & $1.7557( \pm 1.17547)$ \\
Graduates from the same department working there & 349 & $1.6934( \pm 1.20844)$ \\
Flexibility on Attendance & 348 & $1.6868(1.169829)$ \\
Paying Interns & 346 & $1.3006(0.89238)$ \\
\hline
\end{tabular}

Responsible Staff guidance, Work related to Internship Field, Workplace having Necessary Equipment, Interns benefiting from workplace facilities, Meals provided" items were found to be adequate. This assessment presents the participants core expectations and these expectations are met (Table 9). Participants stated that office training contributed primarily towards the "development of computer-aided design program use, the determination of work area for theprofession and the development of written and oral communication skills in professional discipline" (Table 10).

When the participants opinions about the contribution of the office training were questioned, "development of computer- aided design program use, the determination of work area for profession, the development of written and oral communication skills in professional discipline, understanding the ethical attitude of the project, the development of the landscape project design, development of design talent, development of material knowledge, development of three-dimensional computer designs, acquisition of transferring theoretical knowledge to the practice, learning design deficiencies, learning exploration and measurement works, development of project presentation technique, learning project preparation process in the private sector, taking projects from public institutions, learning site work, learning project pricing, developing project contract preparation skills, learning current situation in project offices, development of 
Table 5 : Participants' Ideas on Plantation Internship Institution/Organization

\begin{tabular}{lll}
\hline Criteria & Number of respondents & Average \\
\hline Internship Manager/Responsible Staff & 366 & $3.7596( \pm 1.26149)$ \\
Work related to Internship Field & 361 & $3.6787( \pm 1.25911)$ \\
Workplace having Necessary Equipment & 364 & $3.4533( \pm 1.31343)$ \\
Interns benefiting from workplace facilities & 363 & $3.4050( \pm 1.38806)$ \\
Meals provided & 360 & $3.2639( \pm 1.64201)$ \\
Shuttle Service provided & 362 & $2.3287( \pm 1.56120)$ \\
Transportation fee covered & 361 & $1.9224( \pm 1.41797)$ \\
Intern fee given & 357 & $1.8543( \pm 1.40867)$ \\
\hline
\end{tabular}

Table 6: Participants' ideas about the contribution of plantation internship

\begin{tabular}{lll}
\hline Criteria & Number of respondents & Average \\
\hline Gaining experience in human relations and group work & 366 & $3.6393( \pm 1.23687)$ \\
Learning pruning methods & 361 & $3.5374( \pm 1.32680)$ \\
Learning workers' working system and organization (business management) & 362 & $3.5000( \pm 1.25931)$ \\
Learning irrigation practices & 359 & $3.4930( \pm 1.37387)$ \\
Plant care (fertilization. disinfestation. etc.) applications & 363 & $3.4435( \pm 1.35597)$ \\
Learning herbaceous plant species used in plant design & 366 & $3.4126( \pm 1.31452)$ \\
Learning plantation and greenhouse operations / management & 362 & $3.3923( \pm 1.34216)$ \\
Learning plant production methods & 362 & $3.3840( \pm 1.33525)$ \\
Determining the work area related to the profession & 363 & $3.3581( \pm 1.30177)$ \\
Learning woody plant species used in plant design & 366 & $3.3033( \pm 1.32968)$ \\
Development of oral and written communication skills in professional discipline & 364 & $3.2995( \pm 1.32611)$ \\
Associating theoretical information with application & 363 & $3.2645( \pm 1.30512)$ \\
Understanding professional and ethical responsibilities & 359 & $3.2089( \pm 1.31529)$ \\
Recognizing plant diseases and pests; learning combat methods & 359 & $3.0919( \pm 1.35775)$ \\
Learning the pricing criteria for plants & 365 & $3.0603( \pm 1.39728)$ \\
Learning the current issues about plantation sector & 360 & $2.9944( \pm 1.33309)$ \\
Developing plant design & 359 & $2.9721( \pm 1.32416)$ \\
Learning the discovery and quantification work related to the green field work & 357 & $2.9580( \pm 1.41657)$ \\
Learning the plantation industry and the current situation in Turkey & 360 & $2.8722( \pm 1.28211)$ \\
\hline
\end{tabular}

Table 7 : Participants' ideas on office internship duration

\begin{tabular}{lll}
\hline Ideas related to Duration & Frequency & Ratio $(\%)$ \\
\hline Enough & 246 & 60 \\
Notenough time & 88 & 21 \\
Too much time & 14 & 3 \\
No idea & 12 & 10 \\
Total & 360 & 88 \\
No answer & 51 & 12 \\
Grand total & 411 & 100 \\
\hline
\end{tabular}

construction detailed drawing, observing various laws (zoning law etc.) in application" items were found to be adequate. This evaluation can be expressed as the main contribution obtained from the office internship.

Participants' ideas on the importance of internship training : Participants stated that internship training is important as it helps them to "recognize industry related to profession, compare educational and business life, determine goals after graduation, understand professional responsibilities, understand the profession better, understand the current situation of the profession, understand professional deficiencies, feel professional attachment, learn to work with other disciplines, learn different areas of discipline, apply educational knowledge, reinforce theoretical knowledge" (Table 11). In this context, the participants emphasized that determining the place of internship is very important. They recommended that they should themselves "determine the place of internship or an internship 
Table 8 : Criteria that are effective in participant's preference for office internship

\begin{tabular}{lll}
\hline Criteria & Number of respondents & Average \\
\hline Experienced staff & 349 & $4.0487( \pm 1.23429)$ \\
Landscape architect working in the workplace & 351 & $4.0057( \pm 1.39795)$ \\
Workplace giving importance to internship & 350 & $3.7829( \pm 1.35999)$ \\
Being a good reference for graduates & 351 & $3.7521( \pm 1.33463)$ \\
Being in the city where one lives & 349 & $3.6619( \pm 1.68845)$ \\
Having other inters & 346 & $3.5896( \pm 1.33810)$ \\
Being an ideal place to work after graduation & 350 & $3.3200( \pm 1.40217)$ \\
Training interns & 346 & $3.0925( \pm 1.45168)$ \\
Being one ofthe good places in Turkey & 338 & $2.6213( \pm 1.60075)$ \\
Being in the city where one studies & 351 & $2.0712( \pm 1.62412)$ \\
Department recommendation & 349 & $2.0229( \pm 1.43821)$ \\
Flexibility on attendance & 344 & $1.9477( \pm 1.39455)$ \\
Others' recommendation & 348 & $1.8908( \pm 1.31260)$ \\
Graduates from the same department working there & 348 & $1.8736( \pm 1.39207)$ \\
Notbeing able to find another office & 346 & $1.8237( \pm 1.24440)$ \\
Paying interns & 346 & $1.4624( \pm 1.05777)$ \\
\hline
\end{tabular}

Table 9 : Participants' ideas on the office internship institution/organization

\begin{tabular}{lll}
\hline Criteria & Number of respondents & Average \\
\hline Intern Supervisor/Manager & 354 & $4.1045( \pm 1.18672)$ \\
Internship Related Works & 355 & $4.0366( \pm 1.12059)$ \\
Workplace having Necessary Equipment & 351 & $3.9003( \pm 1.19464)$ \\
Interns benefiting from workplace facilities & 350 & $3.7343( \pm 1.32886)$ \\
Meals provided & 352 & $3.1420( \pm 1.66829)$ \\
Shuttle Service provided & 350 & $2.2543( \pm 1.58102)$ \\
Transportation fee covered & 350 & $1.9029( \pm 1.46075)$ \\
Interns paid & 350 & $1.7114( \pm 1.31102)$ \\
\hline
\end{tabular}

places database from all landscape architecture departments should be used" (Table 12). Furthermore, the participants suggested that "there should be internship related training in the workplace, the process should be supervised, building site internship should be mandatory, plantation internship should be done during vegetation period, and office internship should be divided into as design and planning" in order to increase the internship efficiency (Table 13).

Research findings revealed that participants consider internship as a very important stage of landscape architecture education as stressed by Uzun et al. (2009) andDemiroğlu et al. (2014) as well.

The students expressed that the 30-day period for both internships was sufficient, and majority found anextension of internship unnecessary.Participants particularly emphasized the need for plantation internship to cover the vegetation period as a proposal to increase the internship effectiveness. Erdoğan et al. (2014) have assessed the internship period as too short based on Landscape Architecture Departments' guidelines in Turkey.
The research findings have also shown the choice of internship place as an important factor. For this reason, the presence of experienced staff and landscape architects, theworkplace's with a good reference and its role in giving importance to internship are among the priorities the students have while selecting the internship place. If the internship training is placed in summer vacation, the students desire to do it in cities where they spend the summer. Aydemir (2016) and Karaman et al. (2017) have emphasized that it is very important for students to determine the place of internship by themselves. The firms that will be entered into the database should be determined according to some quality criteria specified by academic staff and students requests. When students opinions about the place of internship are examined, "internship supervisor's guidance, doing internship-related work, having the necessary equipment, interns benefiting from facilities" are among the top priorities, revealing students expectations from an internship place, which acts as an important indicator in determining internship places. Similar expectations are also observed in studies on internships in different fields (Arman and Şahin, 2013; Gürdoğan and Atabey, 2015; Yazarkan and Yılmaz, 2016; Akay et al., 2018; Akın, 2018). 
Table 10 : Participants' ideas about the contribution of office internship

\begin{tabular}{|c|c|c|}
\hline Criteria & Number of respondents & Average \\
\hline Development of computer-aided design program use & 357 & $3.8431( \pm 1.19599)$ \\
\hline Determining the work area for profession & 344 & $3.7645( \pm 1.24297)$ \\
\hline Development of oral and written communication skills in professional discipline & 345 & $3.7507( \pm 1.24425)$ \\
\hline Understanding the ethical attitude of the project & 350 & $3.6829( \pm 1.18466)$ \\
\hline Development of planted landscaping project drawing & 352 & $3.6818( \pm 1.20110)$ \\
\hline Development of structural landscaping project drawing & 353 & $3.6799( \pm 1.22106)$ \\
\hline Development of design ability & 356 & $3.6011( \pm 1.26865)$ \\
\hline Development of material knowledge & 356 & $3.5225( \pm 1.29660)$ \\
\hline Development of three-dimensional computer designs & 354 & $3.4633( \pm 1.41022)$ \\
\hline Ability to transfer theoretical knowledge to practice & 350 & $3.4543( \pm 1.28332)$ \\
\hline Learning design deficiencies & 352 & $3.4543( \pm 1.28332)$ \\
\hline Learning exploration and measurement works & 352 & $3.3920( \pm 1.36281)$ \\
\hline Development of project presentation technique & 348 & $3.3563( \pm 1.33649)$ \\
\hline Learning project preparation process in private sector & 350 & $3.3029( \pm 1.42822)$ \\
\hline Learning project preparation process in public institutions & 350 & $3.2429( \pm 1.42064)$ \\
\hline Learning construction site works & 351 & $3.2108( \pm 1.43068)$ \\
\hline Learning project pricing & 348 & $3.2108( \pm 1.43068)$ \\
\hline Development project contract file preparation & 353 & $3.1501( \pm 1.49340)$ \\
\hline Learning the current situation in project offices & 353 & $3.0623( \pm 1.38234)$ \\
\hline Development of construction detailed drawing & 352 & $3.0540( \pm 1.37331)$ \\
\hline Observing various laws (Zoning Law etc.) in application & 347 & $3.0115( \pm 1.34288)$ \\
\hline Development of various drawing skills (perspective. sketch. design. etc.) & 353 & $2.9433( \pm 1.42907)$ \\
\hline Learning of different computer programs used in design. planning & 344 & $2.9390( \pm 1.50772)$ \\
\hline Learning of Inspector service & 349 & $2.9341( \pm 1.40758)$ \\
\hline Development of application project drawing & 350 & $2.9029( \pm 1.4902)$ \\
\hline Development of lighting project drawing & 352 & $2.7614( \pm 1.42020)$ \\
\hline Development of irrigation project drawing & 351 & $2.7293( \pm 1.45728)$ \\
\hline Development of drainage project drawing & 353 & $2.6771( \pm 1.47439)$ \\
\hline Learning of different computer programs used in project presentation & 336 & $2.6161( \pm 1.51162)$ \\
\hline
\end{tabular}

When the contributions obtained from the office and plantation internship were questioned within the scope of this study, students expressed their opinions about how they gained experiences related to work life and practical work. These ideas confirm the theoretical knowledge of the internship and other studies. In addition, participants highlighted that internship is quite essential in terms of reinforcing theoretical knowledge, observing differences between education and work life, recognizing the professional industry, and experiencing interdisciplinary work. Karacan and Karacan (2004), Bahadır and Oğuz (2012) and Karaman et al. (2017) have indicated that internship contributed to these issues in education.

Participants emphasized that office internship should be divided into two as design and planning and construction site internships should also be included. Competition in the business world, evolving technology and its applications, revive the issue of more experienced and educated workforce. Education is the most effective way to deal with these conditions. Internship training is one of the key points of this process since it gives a real-life experience. The situation is same for landscape architecture education and internship is an important part of education. The findings of the study revealed that the internship period and time were insufficient, the type of internship was inadequate, the choice of internship place was problematic and the internship process was not followed.

The findings also show that the information about the internship was not enough during the education process. As a result, the internship process in landscape architecture education in Turkey can not be utilized in an efficient manner. This situation is a big loss in terms of applied education which is a practical education. In this context, the following suggestions have been developed in order to increase the productivity of internship and its contribution to education.

The internship period must be extended. The duration should be arranged to cover the longest internship period on the basis of undergraduate education policies in the country. In this process, students should be provided with office (planning and design), construction site and nursery experiences. Internship timings should be made at times that are appropriate for the type of internship. For example, nursery internship should be done during vegetation period and construction site internship should be done in construction calendar period. 
Table 11 : Participants' ideas about the importance of internship training

\begin{tabular}{lll}
\hline Contribution & Number of respondents & Average \\
\hline Recognition of professional sector & 387 & $4.3437( \pm 0.89224)$ \\
Comparing education and business & 392 & $4.3367( \pm 0.88689)$ \\
Determination of goals after graduation & 391 & $4.2992( \pm 0.905819)$ \\
Understanding professional responsibilities & 391 & $4.2941( \pm 0.90466)$ \\
Better understanding of the profession & 392 & $4.2883( \pm 0.90809)$ \\
Understanding the current situation in profession & 388 & $4.2835( \pm 0.90764)$ \\
Recognizing professional deficiencies & 393 & $4.2824( \pm 0.92534)$ \\
Feeling professional attachment & 392 & $4.2704( \pm 0.94522)$ \\
Learning to work together with other disciplines & 388 & $4.1701( \pm 0.99192)$ \\
Learning different areas of the discipline & 386 & $4.0959( \pm 0.97161)$ \\
Applying educational knowledge & 391 & $4.0307( \pm 1.08561)$ \\
Reinforce theoretical knowledge & 391 & $3.6777( \pm 1.18256)$ \\
Realization of a formality to be fulfilled to graduate & 385 & $2.7481( \pm 1.53481)$ \\
\hline
\end{tabular}

Table 12 : Participants' suggestions on determining internship place

\begin{tabular}{lll}
\hline Suggestions & Number of respondents & Average \\
\hline Choosing one's own internship place & 391 & $4.2583( \pm 1.04625)$ \\
Choosing from internship database & 383 & $3.8068( \pm 1.29204)$ \\
DepartmentDecides & 383 & $2.5039( \pm 1.38593)$ \\
\hline
\end{tabular}

*Should be created with the contribution of all landscape architecture departments

Table 13: Suggestions to improve internship effectiveness

\begin{tabular}{lll}
\hline Suggestions & Number of respondents & Average \\
\hline Internship training program should be made in the workplace & 396 & $4.6288( \pm 1.13102)$ \\
Internship process should be supervised & 388 & $4.0902( \pm 1.14102)$ \\
Abuilding site internship should be compulsory & 391 & $3.9335( \pm 1.25297)$ \\
Plantation internship should be during vegetation period & 386 & $3.8756( \pm 1.12126)$ \\
The office internship should be divided into as design and planning. & 392 & $3.7602( \pm 1.31824)$ \\
Internship times should be changed & 394 & $2.9112( \pm 1.42308)$ \\
\hline
\end{tabular}

Internship database can be created on the basis of interdepartmental (landscape department) coordination in order to solve the problem of internship site selection. In this context, various quality criteria should be determined for selecting companies to be included in the database. In this process, policies that regulate the relations and coordination between landscape architecture departments, student and internship place should be developed, and the responsibility of each member of this system to each other should be defined. The internship process should be supervised. Inspections should be carried out by the internship responsibilities in the departments. Internship evaluation should also be done by the trainee responsible. This evaluation process should be documented.

The importance and necessity of the internship, working principles and responsibilities during the internship process should be given to the student during the education process.

\section{References}

Anonymous: Çanakkale Onsekiz Mart University Faculty of Architecture and Design Internship Directive. http://mtf.comu.edu.tr/images/ form/dosya/dosya_721136.pdf(2015).

Akay, B., A. Uslu and M.F. Sancar: Tourism education students live problems in internship periods: Undergraduate and secondary. Tourism students sample. Int. J. Soc. Res., 8, 212-236 (2018).

Akın, A.: Importance of internship training in gastronomy tourism: The case of Gaziantep University. Igdir Uni. J. Soc. Sci., 16, 483-518 (2018).

Atik, A., B. Yılmaz, F. Aslan, O. Ateş and E. Taçoral: A study on the determination of landscape architecture students' expectations from their education and profession in the sample of İnönü University. Inönü Univ. J. Art Des., 3, 105-122 (2013).

Arman, A. and T. Şahin: Expectations of hotel management and tourism vocational high school Students from establishment during their training: Mengen cooking hotel management and tourism vocational high school case study. Uşak Univ. J. Soc. Sci., 6, 13-24 (2013). 
Aydemir, D.H.: Determination of the opinions of the students of vocational school towards summer internship education. Tur. J. Life Sci., 1, 34-42 (2016).

Bahadır, M. and H. Oğuz: The determination of Selçuk University Higher School of Vocational And Technical Sciences students make training. Iğdır Univ. J. Inst. Sci. Tech., 2, 69-76 (2012).

Çetin, Ş.: An exploratory study of the courses useful in internship: A case study on mersin school of tourism and hotel management. Anatolia J. Tour., 16, 153-169 (2005).

Dağıstanlığlu, C., C. KuşŞahin and S. Akten: A research for determination of SDU vocational school landscape graduated people's attitudes towards their jobs. SDU J. Tecn. Sci., 2, 12-17 (2012).

Demiroğlu, D., S. Görmüş, T. Birişçi, R. Erdoğan, A. Kalaycı, A.A. Karadağ and I. Sezen: Importance of internship in student oriented landscape architecture education. Landscape architecture education and training workshop. 10-12 Nisan, Antalya, 251-265 (2014).

Duran Gökalp, D. and M.E. Yazgan: Agrotourism and agriturism in rural landscape planning. KMUJ. Soc. Econ. Res., 15, 25-29 (2013).

Erdoğan, R., I. Sezen, T. Birişçi, D. Demiroğlu, S. Görmüş, A. Kalaycı and A.A. Karadağ: Internship applications in landscape architecture education in I. Landscape Architecture Education and Training Workshop. 10-12 Nisan, I, Antalya, 227-237 (2014).

Güngör, D.: Guidance on the development and adaptation of measurement tools in psychology. Turk. Psychol. Writi., 19, 104$112(2016)$

Gürdoğan, A. and S. Atabey: Guidance on the development and adaptation of measurement tools in psychology. Turkish psychology writings, effect of satisfaction journal of economics and management research on level of students from internship on their career goals. J. Econ. Manag. Res., 4, 91-113 (2015).

Kalaycı, A., A.A. Karadağ, T. Biriş̧̧i, D. Demiroğlu, R. Erdoğan, S. Görmüş and I. Sezen: Evaluating the internship opportunities and practices in the departments of landscape architecture in the world. I. Landscape Architecture Education and Training Workshop, 10-12 Nisan, Antalya, pp. 239-249 (2014).

Karacan, S. and E. Karacan: Vocational Schools (Vocational School) A
Research on Internship Applications: Quality and Efficiency of Business-Vocational School Collaboration Requirement, Koc. Univ. Inst. Soc. Sci. J., 8, 168-184 (2004).

Karaman, A., A.E. Metin and Ş. Güven: Determination of forestry program students' tendency of internship training: Usak University Case. Kara. Univ. Inst. Soc. Sci. J., 7, 101-106 (2017).

Kesim, G.A. and S.G. Mansuroğlu: Some opinions and suggestions about landscape architecture education in our country. First Congress of Landscape Architecture. Ankara, 19-21 Ekim, pp. 547-554 (2000).

Nijhuis, S.: Principles of Landscape Architecture. Flowscapes Exploring Landscape Infrastructures, Edt: Elena Farini, Steffen Nijhuis, Publishedby de Vitoria University, Spain, 53-61 (2013)

Olcay, A., I. Yıldırım and M. Sürme: The tourism department students' opinions about Internship training: Case of Gaziantep Province. J. Hig. Educ. Sci., 5, 324-334 (2015).

Rhoades, J.D.: Cation exchange capacity. Methods of Soil Analysis, Part 2, Chemical and Microbiological Properties. $2^{\text {nd }}$ Edn., (Ed: A.L. Page). Soil Sci. Soc. of Amer. Inc., Madison, Wisconsin, 149-157 (1982).

Uzun, O. and G.A. Kesim: Landscape architecture education in 21st century.150. Forestry Education in Turkey in the year. III. National Forestry Congress. http://akademikpersonel.duzce.edu.tr/ gunizkesim/bildiri/gunizkesim02.08.2010_20.29.32bildiri.pdf. (E. T. 01.09.2013) (2008).

Uzun, O., P. Köylü, Z. Demir, Müderrisoğlu, A.A. Karadağ, S. Özkan Aydın, S. Uzun, P. Girti and G. AkıncıKesim: Evaluation of internship in terms of student and employer in landscape architecture education; Düzce University Landscape Architecture Department example. Bartın Journal of Forestry, I. National Western Black Sea Forestry Congress, Special Issue, pp. 519-531 (2009).

Yıldız, N.D., M. Demir, B. Aytatı and T.H. Göktuğ: Woman in landscape architecture education. Inonu Univ. J. Art Design., 2, 1074-1083 (2011).

Yazarkan, H. and Z. Yılmaz: Problems and expectations of accounting trainees in internship training: An application in TR90 region. Atat. Uni. J. Econo. Admini. Sci., 30, 285-302 (2016). 